\title{
Predation on Invasive Snails, the Red-rimmed Melania (Melanoides tuberculata) and the Giant Ramshorn Snail (Marisa cornuarietis), by the Eastern Musk Turtle (Sternotherus odoratus) in a Texas Spring
}

Madeleine Morrison ${ }^{1}$, Brian P. Butterfield ${ }^{2}$, Andrew Walde ${ }^{3}$, Stephen G. Ross ${ }^{4}$, Chris Collins ${ }^{5}$, and Eric Munscher ${ }^{3,6}$

\author{
${ }^{1}$ University of New England, Biddeford, Maine 04005, USA \\ ${ }^{2}$ Freed-Hardeman University, Henderson, Tennessee 38340, USA \\ ${ }^{3}$ Turtle Survival Alliance, North American Freshwater Turtle Research Group, Fort Worth, Texas 76110, USA \\ ${ }^{4}$ Power Engineers, Inc., Houston, Texas, USA \\ ${ }^{5}$ SWCA Environmental Consultants, San Antonio, Texas 78249, USA \\ ${ }^{6}$ SWCA Environmental Consultants, Bridgeville, Pennsylvania 15017, USA (emunscher@swca.com)
}

Photographs by Brian W. Bower.

$\mathrm{T}$

The Eastern Musk Turtle (Sternotherus odoratus; Fig. 1), has one of the largest ranges of any freshwater turtle in North America. It ranges from eastern Canada south through Florida and west into central Texas (Mahmoud 1969; Powell et al. 2016). Within a given ecosystem, this species is known to occupy the littoral zone of the water column, where individuals prey upon various organisms, including gastropods and bivalves (Ford and Moll 2004). In recent years, S. odoratus is known to prey on invasive bivalves such as Zebra Mussels (Dreissena polymorpha; Patterson and Lindeman
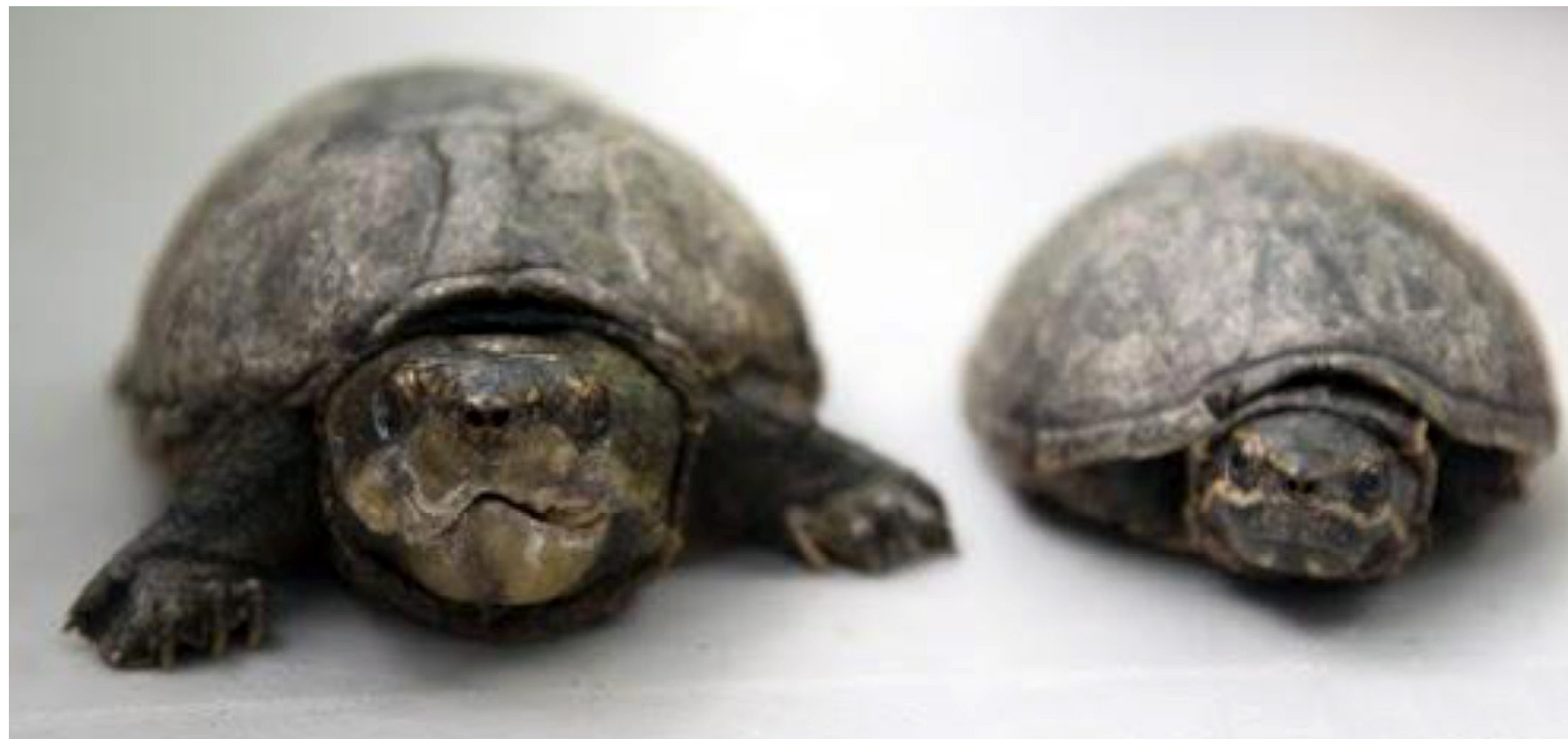

Fig. 1. Adult Eastern Musk Turtles (Sternotherus odoratus) captured at Comal Springs, New Braunfels, Texas. Note the pronounced head width on the individual on the left. This head size is common at Comal Springs. 
2009) and Asian Clams (Corbicula fluminea; Wilhelm and Plummer 2012), but has not been documented preying on invasive snails. Herein we report the first observation of predation by $S$. odoratus on two species of invasive snails.

Since 2012, the Turtle Survival Alliance North American Freshwater Turtle Research Group (TSA-NAFTRG) has conducted a turtle population survey at Comal Springs in New Braunfels, Texas. This spring distributes a consistent water flow of approximately $726,799,000$ liters per day with stable, yearround temperatures ranging from about $23.1{ }^{\circ} \mathrm{C}$ to $23.9^{\circ} \mathrm{C}$ (Brune 1981). However, this spring also harbors two species of invasive snails, the Giant Ramshorn Snail (Marisa cornuarietis, Fig. 2; Horne et al. 1992) and the Red-rimmed Melania (Melanoides tuberculata; Fig. 3; Murray 1964). While the first recorded occurrence of $M$. tuberculata in the Comal Springs ecosystem occurred in the 1960s (Murray 1964) and the first recorded occurrence of $M$. cornuarietis in Comal Springs was recorded in the 1980s (Horne et al. 1992), we are unaware of any reports of $S$. odoratus preying on either of these snails.

However, over the past four years, we have observed $S$. odoratus actively preying upon both species of invasive snails. These observations usually involved capturing the turtles while they were visibly attacking something in the substrate, only to find out that what they were eating was an invasive gastropod. In fact, researchers often catch the turtles with the invasive snails in their mouths. Volunteers also have reported

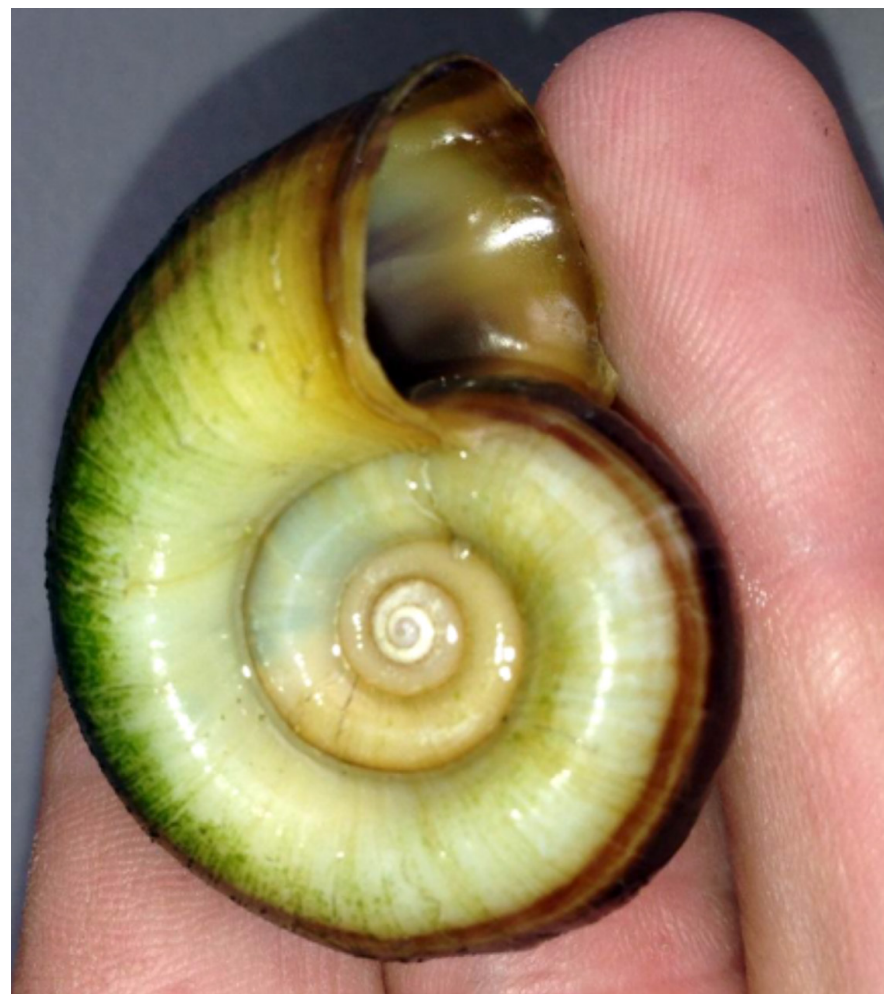

Fig. 2. A Giant Ramshorn Snail (Marisa cornuarietis) taken from Comal Springs, New Braunfels, Texas. This invasive species has become prolific within the Comal Springs ecosystem.

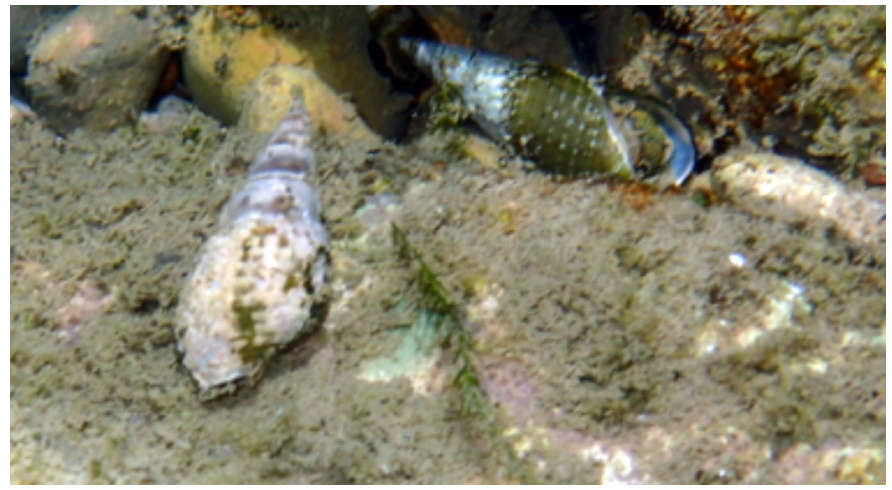

Fig. 3. Red-rimmed Melania (Melanoides tuberculata) taken from Comal Springs, New Braunfels, Texas. This invasive species has become prolific within the Comal Springs ecosystem.

large adult $S$. odoratus actively cracking the shells of $M$. cornuarietis and consuming the large snails in portions. We chose to further investigate predation by $S$. odoratus by examining the contents of the turtles' fecal samples.

We captured a total of 46 turtles by hand during a quarterly sampling session on 2-4 February 2013 for fecal sample analysis. Turtles were individually placed in plastic containers overnight to allow the turtles an opportunity to defecate. We placed fecal samples in a freezer to preserve any fragile materials and then filtered and sorted samples using a small lab spatula and forceps. We then attempted to identify gastropod shell fragments to species. Of the 46 turtles, only 15 produced fecal samples. Of the 15 fecal samples, 13 contained shell fragments from gastropods. Of these, 11 were confirmed to be from $M$. tuberculata. Shell fragments from the remaining two samples were too crushed to be clearly identified; however, we suspect that they were likely from $M$. cornuarietis.

With documentation that the $S$. odoratus population in Comal Springs does prey on two invasive snail species, we are interested in exploring how these interactions are affecting each species. Is predation by a robust $S$. odoratus population (Fig. 4) regulating populations of either invasive snail species at Comal Springs? Likewise, is the addition of these prey species influencing the reproductive biology, physiology, or morphology of $S$. odoratus at Comal Springs? These are questions we hope to answer with future research.

\section{Acknowledgements}

We thank the City of New Braunfels for allowing us to conduct this study in Comal Springs. We also thank Chris Maldonado from Texas Parks and Wildlife for granting permits to conduct this project for the past four years. Additional thanks to the NAFTRG volunteers for participating over the course of the project. We also acknowledge SWCA Environmental Consultants for their constant support. Additionally, we thank Brian W. Bower for providing us with the photographs used in this document. 


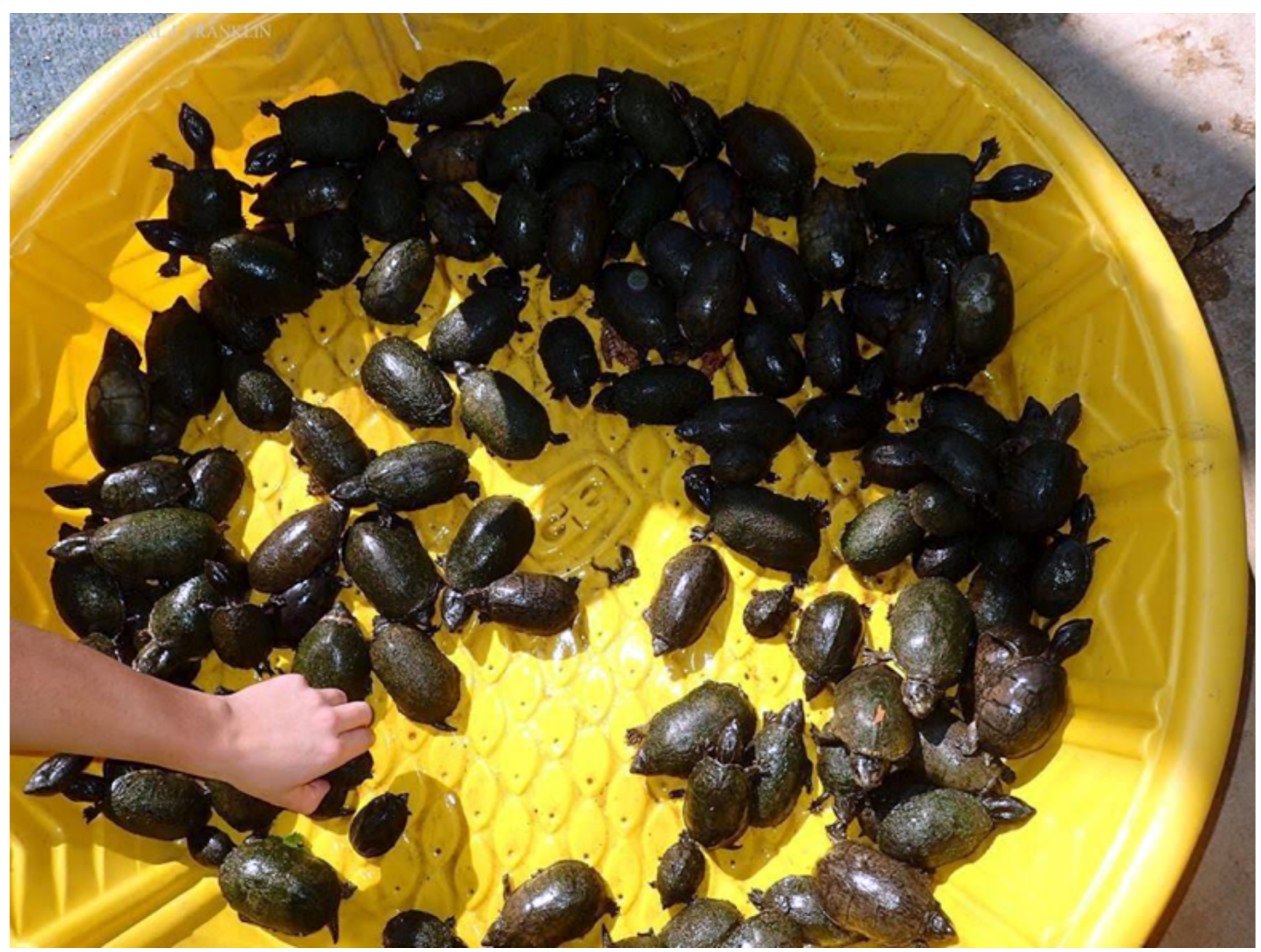

Fig. 4. Eastern Musk Turtles (Sternotherus odoratus) captured during a quarterly population survey at Comal Springs, New Braunfels, Texas.

\section{Literature Cited}

Brune, G. 1981. Springs of Texas: Volume I. Texas A\&M University Agriculture Series. Branch-Smith, Inc., Fort Worth, Texas.

Horne, F.R., T.L. Arsuffi, and R.W. Neck. 1992. Recent introduction and potential impact of the Giant Rams-horn Snail, Marisa cornuarietis (Pilidae), in the Comal Springs ecosystem of Central Texas. Southwestern Naturalist 37: 194-214.

Ford, D.K. and D. Moll. 2004. Sexual and seasonal variation in foraging patterns in the Stinkpot, Sternotherus odoratus, in southwestern Missouri. Journal of Herpetology 38: 296-301.

Mahmoud, I. 1969. Comparative ecology of the kinosternid turtles of Oklahoma. Southwestern Naturalist 14: 31-66.
Murray, H.D. 1964. Tarebia granifera and Melanoides tuberculata in Texas. American Malacological Annual Reports 1964: 15-16.

Patterson, J. and P. Lindeman. 2009. Effects of Zebra and Quagga Mussel (Dreissena spp.) invasion on the feeding habits of Sternotherus odoratus (Stinkpot) on Presque Isle, northwestern Pennsylvania. Northeastern Naturalist 16: 365374.

Powell, R., R. Conant, and J.T. Collins. 2016. Peterson Field Guide to Reptiles and Amphibians of Eastern and Central North America. 4th ed. Houghton Mifflin Harcourt Publishing Co., Boston, Massachusetts.

Wilhelm, C.E. and M.V. Plummer. 2012. Diet of radiotracked Musk Turtles, Sternotherus odoratus, in a small urban stream. Herpetological Conservation and Biology 7: 258-264. 